Trakya Eğitim Dergisi

Cilt 9, Sayı 1

Ocak 2019, 161-172

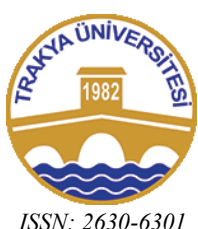

Doi: $10.24315 /$ tred.469661
Trakya Journal of Education

Volume 9, Issue 1

January 2019, 161-172

\title{
Trakya Üniversitesi Uluslararası Öğrenci Profilini ve Oryantasyon Gereksinimlerini Belirleme Çalışması ${ }^{1}$
}

\author{
Determination Study of Trakya University International Student Profile and \\ Assessment of Orientation Requirements
}

\section{Oya ONAT KOCABIYIK², Seda DONAT BACIOĞLU ${ }^{3}$}

\begin{abstract}
Öz: $\quad \mathrm{Bu}$ araştırmanın amacı, Trakya Üniversitesi’nde öğrenim gören uluslararası öğrencilerin profilini ve oryantasyon gereksinimlerini belirlemektir. Araştırmanın örneklemini 20172018 eğitim-öğretim yılında, Trakya Üniversitesi’ne yeni kayıt yaptıran, hazırlık ve birinci sınıfta okuyan uluslararası ögrenciler oluşturmaktadır $(\mathrm{N}=171)$. Araştırma betimsel tarama modelinde olup, araştırmada "Öğrenci Profili Anketi" ile "Yeni Kayıt Yaptıran Öğrenciler için Oryantasyon Gereksinimlerini Değerlendirme Anketi" kullanılmıştır. Elde edilen verilerin analizinde frekans ve yüzdelik dağılımları kullanılmıştır. Araştırmanın bulgularına göre, öğrencilerin daha çok sağlık ve eğitim alanını tercih ettikleri sonucuna ulaşılmıştır. Ayrıca kaliteli eğitim göreceklerini düşündükleri için Trakya Üniversitesi'ni ilk sıralarda tercih ederek geldikleri belirlenmiştir. Öğrencilerin üniversite ile ilgili özellikle bölüm, staj ve burs programları, yerleşke ve yakın çevresi, yerleşkede bulunan sosyal faaliyetler ve psikolojik danışma hizmetleri ile ilgili oryantasyon gereksinimleri olduğu tespit edilmiştir.
\end{abstract}

Anahtar sözcükler: Uluslararası Öğrenci, ögrrenci profili, oryantasyon.

Cite this article as:

Onat Kocabıyık, O.\& Donat Bacıŏ̆lu, S. (2019). Trakya Üniversitesi uluslararasi öğrenci profilini ve oryantasyon gereksinimlerini belirleme çalişması. Trakya Ĕ̈itim Dergisi, 9(1), 161-172.

\section{Introduction}

\section{EXTENDED ABSTRACT}

Orientation services are included in student personality services and they are services based on the program designed to help students adapt to the university. International student orientation has become an important issue for universities in recent years. The reason is to increase the number of international students with the aim of internationalization in higher education. According to the Higher Education Institution statistics on 2017-2018 academic year, there is a total of 125138 international students enrolled in universities in Turkey. This also requires some improvements and arrangements for the students. When the literature is examined, it is seen that there are a lot of studies about the problems experienced by international students but there are limited studies about international student orientation which should be among the suggestions to solve these problems. The aim of this study is to determine the profile of Trakya University international students and their orientation needs. The results

\footnotetext{
${ }^{1}$ Bu çalıșmanın özeti "13. Uluslararası Balkan Eğitim ve Bilim Kongresinde” sözlü bildiri olarak sunulmuștur.

${ }^{2}$ Dr. Öğr. Üyesi, Trakya Üniversitesi, e-posta: oyaonat@trakya.edu.tr

${ }^{3}$ Dr. Öğr. Üyesi, Trakya Üniversitesi, e-posta: sedadonatbacioglu@trakya.edu.tr
} 
are expected to contribute to the orientation needs of international students and the orientation programs to be developed by universities to meet these needs.

\section{Method}

In this research, survey method was used to determine the profile and orientation needs of international students of Trakya University. The population of the study consists of international students enrolled in the faculties and schools of the Trakya University central campus during the 20172018 academic year $(\mathrm{N}=707)$. The sample of the research; international students who are newly enrolled in Trakya University and who are in preparatory and first year were chosen by random assignment $(\mathrm{N}=171)$. In the research, "Students Profile Inventory" developed by the researchers and "Inventory of Determining Orientation Needs of University Students Newly Enrolled" developed by Özyürek, Arıkan ve Şahin (2016) were used. In this inventory, there are questions about the needs of the students to get information about the campus and its surroundings, to introduce the activities in the campus, information on the protection of psychological health, and to benefit from psychological counseling and guidance services. In the analysis of the data, content analysis was used and the results were given as frequency and percentage distribution.

\section{Result and Discussion}

The results for determining the international student profile, which is the primary objective of the research, are as follows: The majority of the international students at Trakya University consist of students who start the university graduated from high school, live in the village / town in the country they live in, live in the dormitory in the campus and take a spending money from their family. The students preferred health sciences and education faculties. Most of them settled in their first choice. The most preferred reasons for choosing Trakya University are quality in education and university entrance score; the least preferred reason; internet research and promotion are affected. Among the reasons affecting the department preference were the most special interest, employment and family effect. They are affected by at least promotions. According to international higher education mobility and Turkey's position report (DEIK, 2013), students prefer the country and department giving best education according to their business in the future.

The second aim of the study is to determine the orientation needs of international students; students need to get information about the social activities in the nearby environment and campus. Since students take a long time to get to know the environment, they try to learn something through trial and error and cause adaptation problems. Therefore, support activities should be carried out for students' needs. Orientation activities, introductory activities they want students to have in their departments. Students want to meet international students who are most like themselves. Most of them find communication with other individuals stressful (Özçetin, 2013). Because of the fact that they are looking for friendships close to their own culture, the guidance of international students in upper classes can be used. In the context of counseling and guidance, international students need assistance; often, the anxiety of exam, coping with stress, efficient study, career development and job application, decision-making ability and assertiveness; students are most in need of individual counseling service. The university decrease their anxiety in the registration period by giving information about registration, education programme and evaluation system.

Counseling services should be sensitive to the problems of international students to support the adaptation of the students. Student profile studies are important in terms of recognizing the characteristics of the students who prefer the university. In this way, universities can make improvements and arrangements for the current profile. It will be more appropriate to prepare an orientation program that will meet the students' orientation needs rather than to organize random orientation activities. It is an indisputable reality that international students experience a process of adaptation problem. Therefore, the establishment of a consultancy unit in which the students can get support in their living areas (school, dormitory, etc.), supporting these units by the expert staff will be effective in eliminating the psychological risks and problems they may face (Otrar et al., 2002).

The results of the study show that there is a need for a well-planned and programmed orientation model that can serve the needs, development and adaptation of international students according to the aims and conditions of the university. 


\section{GİRIŞ}

Oryantasyon hizmetleri, öğrenci kişilik hizmetleri içinde yer alan, üniversite yaşamına yeni başlayan öğrencilerin yeni ortamlarına alışmalarına yardımcı olmak amacıyla yürütülen planlı programlı hizmetlerdir. İlk bakışta oryantasyon, yeni kayıtla gelen öğrencilere yönelik eğitim-öğretim yılının başlamasını takiben ilk haftalarda okula uyum sağlama amacıyla yapılan çalışmalar gibi görünse de aslında yıl boyunca devam eden çalışmalar olduğunun ve sonraki yıllarda da kendini yenileyerek devam eden bir süreç olduğunun altını çizmek gerekmektedir. Türkiye' deki üniversitelerde oryantasyon hizmetlerinin verilmesiyle ilgili yönetmelikler çok eski bir geçmişe sahip değildir. 2547 sayılı Yükseköğretim Kanunu'nda yapılan değişiklikle (T.C. Resmî Gazete, 1984) üniversitelerde psikolojik danışma ve rehberlik hizmetleri için yasal çerçeveler belirlenmiştir (Akbalık, 1999; Kutlu, 2004). Hizmetlerin kapsamında, oryantasyon, kariyer psikolojik danışması, bireyle ve grupla psikolojik danışma gibi çalışmalardan söz edilmiştir. Bu amaçla Türkiye'deki üniversitelerde oryantasyon programları farklı düzeylerde de olsa düzenlenmektedir. Oryantasyon çalışmaları kapsamında, sıklıkla tanıtım programları, akran rehberliği, geziler, konferans-panel gibi etkinlikler üniversitelerce yapılmaktadır.

Uluslararası öğrenci oryantasyonu ise son yıllarda üniversitelerin çok önem verdikleri bir konu haline gelmiştir. Eğitimin artan önemi ile yükselen talep ve bunu karşılamak için, eğitim hizmetlerinden daha yüksek pay alma çabası ile uluslararası alanda oluşmuştur. Artan rekabete küreselleşme ve teknolojik değişimin etki ve sonuçları da eklenince eğitim-öğretimde, özellikle yükseköğrenimde uluslararası öğrenci hareketliliği canlanmıştır (Sağırlı, 2007). Yüksek Öğretim Kurumunun 2017-2018 eğitim-öğretim yılı istatistikleri Türkiye'deki üniversitelere kayıtlı toplamda 125.138 uluslararası öğrenci bulunduğu yönündedir (YÖK istatistikleri, 2018). Yükseköğretimde uluslararasılaşmanın hedefinde olan uluslararası öğrenci sayısının arttırılması beraberinde bu öğrenciler için üniversiteyi çekim merkezi haline getirmek üzere işleyişte bazı iyileştirmeler ve düzenlemeler yapmayı da zorunlu kılmaktadır. Bunlar arasında, üniversitelerin fiziki ve akademik altyapısının ve sosyal imkânlarının uluslararası öğrenciler için hazır hale getirmesi, İngilizce ve diğer temel dillerde eğitim imkânı sağlaması, fiyatlandırma ve diplomaların diğer ülkelerde tanınması ön koşul olarak görülmektedir. Uluslararası öğrenciler, yeni bir kültürle ilk temaslarından itibaren eğitim sürecinin tamamında kendilerine yol gösterecek ve sorunlarına çözüm bulacak bir yapıya ihtiyaç duymaktadırlar. Yurt dışındaki uygulamalarda uluslararası öğrenci ofisleri olarak adlandırılan birimler oryantasyon sürecine dahil olmak üzere öğrencilerin eğitim gördükleri süre zarfında önemli bir rol üstlenmektedir.

Alanyazın incelendiğinde, uluslararası öğrencilerin yaşadıkları sorunları ortaya koymaya yönelik çok fazla çalışma (Acar Güvendir, 2018; Kıroğlu, Kesten ve Elma, 2010; Kılıçlar, Sarı ve Seçilmiş, 2012; Özçetin, 2013; Zhang ve Goodson, 2011) olduğu görülmüştür. Örneğin; Cura ve Işık (2016) tarafindan yapılan bir çalışmada, uluslararası öğrencilerin uyumları ile aile, arkadaşlar ve kurum tarafindan sağlanan desteğin seviyesi arasında pozitif yönlü ve anlamlı bir ilişki olduğu görülmektedir. Araştırmanın sonucu olarak aile, arkadaşlar ve kurum tarafından sağlanan destek, uluslararası öğrencilerin uyum seviyelerini arttırmaktadır. Coşkunserçe ve Bedir-Erişti (2017), uluslararası öğrencilerin kültürel uyum sürecine yönelik tasarım tabanlı araştırma yaklaşımına dayalı çevrimiçi oryantasyon uygulaması geliştirdikleri çalışmalarının sonucunda, çevrimiçi sistem ile uluslararası öğrencilere sunulan danışmanlık hizmetinin etkili olduğu görülmüştür.

Uluslararas1 öğrencilerin uyum sürecini kolaylaştıran oryantasyon hizmetlerinin önemi ve gerekliliğinden yola çıkarak buradan elde edilecek sonuçların, uluslararası öğrencilerin oryantasyon gereksinimlerini ve bu gereksinimleri karşılamaya yönelik üniversitelerce uygulanmak üzere geliştirilecek oryantasyon programları ile ilgili çalışmalara katkı sağlayacağı düşünülmektedir. Özellikle bu çalışmada diğer çalışmalardan farklı olarak Trakya Üniversitesi'ne yeni kayıt yaptıran uluslararası öğrencilerin oryantasyon gereksinimleri belirlenerek üniversite tarafindan geliştirilebilecek oryantasyon programına fayda sağlayabilir.

Bu nedenle araştırmanın amacı, Trakya Üniversitesi uluslararası öğrencilerinin profilini belirlemek ve oryantasyon gereksinimlerini incelemektir. Bu temel amaç kapsamında aşağıdaki sorulara cevap aranmıştır;

1. Trakya Üniversitesi'ne yeni kayıt yaptıran uluslararası öğrencilerin profili nasıldır?

2. Trakya Üniversitesi'ne yeni kayıt yaptıran uluslararası öğrencilerin oryantasyon gereksinimleri nelerdir? 


\section{YÖNTEM}

$\mathrm{Bu}$ araştırmada, Trakya Üniversitesi uluslararası öğrencilerinin profilini ve oryantasyon gereksinimlerini belirlemek üzere betimsel araştırma yöntemi kullanılmıştır. Araştırmanın evreni, 2017-2018 eğitim-öğretim y1lında Trakya Üniversitesi merkez kampüsü bünyesindeki fakülte ve yüksekokullarda kayıtlı uluslararası öğrencilerden meydana gelmektedir (N=707). Araştırmanın örneklemini ise; seçkisiz atama yöntemiyle belirlenmiş Trakya Üniversitesi'ne yeni kayıt yaptıran, hazırlık ve birinci sınıfta okuyan uluslararası öğrenciler oluşturmaktadır $(\mathrm{N}=171)$. Örneklemde yer alan öğrencilere araştırmacılar tarafından geliştirilen "Öğrenci Profili Anketi” ve Özyürek, Arıkan ve Şahin (2016) tarafından geliştirilen "Yeni Kayıt Yaptıran Öğrenciler için Oryantasyon Gereksinimlerini Değerlendirme Anketi” uygulanmıştır.

Öğrenci Profili Anketinde; yaş, cinsiyet, bölüm, fakülte/yüksekokul, hayatının büyük bölümünü geçirdiği yer, Edirne'de nerede yaşadıkları, aylık bireysel giderlerini nasıl karşıladıkları, Anne, baba eğitim durumu, Trakya Üniversitesini ve okuduğu bölümü tercih etme nedenleri ve boş zamanlarını nasıl değerlendirdikleri gibi sorular yer almaktadır. Sorular için seçenekler sunulmuş ve öğrencilerin birden fazla seçeneği işaretleyebilmesine firsat verilmiştir. Elde edilen veriler içerik analizi yapılmış, sonuçların gösterilmesinde frekans ve yüzdelik dağılımlarına yer verilmiştir.

Yeni Kayıt Yaptıran Öğrenciler için Oryantasyon Gereksinimlerini Değerlendirme Anketinde ise; öğrenim göreceği yerleşke ve yakın çevresiyle, yerleşkede bulunan faaliyetlerin tanıtılmasıyla, psikolojik sağlıkların korunması ve geliştirilmesiyle, yararlanmak istedikleri psikolojik danışma ve rehberlik hizmetleriyle ilgili bilgilerin yer aldığı sorular sorulmuştur. Bu başlıklar altında yer alan sorular için seçenek sunularak öğrencilerin birden fazla seçeneği işaretleyebilmesine olanak verilmiştir. Verilerin analizinde, içerik analizi kullanılmış, sonuçların frekans ve yüzdelik dağılımları verilmiştir.

\section{BULGULAR}

Tablo 1. Cinsiyet, hayatının büyük bölümünü geçirdiği yer, Edirne'de yaşadığı/yaşayacağı yer ve aylık bireysel giderlerini karşılama değişkenine ait frekans ve yüzdelik dağılım

\section{1. Öğrenci Profiline İlişkin Bulgular}

\begin{tabular}{|c|c|c|}
\hline Cinsiyet & $\mathbf{f}$ & $\%$ \\
\hline Kadın & 124 & 72.5 \\
\hline Erkek & 42 & 27.5 \\
\hline Toplam & 171 & 100.0 \\
\hline $\begin{array}{l}\text { Hayatının Büyük Bölümünü } \\
\text { Geçirdiği Yer }\end{array}$ & f & $\%$ \\
\hline Köy-Kasaba & 68 & 39.8 \\
\hline Büyükşehir & 43 & 25.1 \\
\hline İl & 42 & 24.6 \\
\hline İlçe & 18 & 10.5 \\
\hline Toplam & 171 & 100.0 \\
\hline Yaşadığı Yer & f & $\%$ \\
\hline Yurt & 108 & 63.2 \\
\hline Ev & 60 & 35.1 \\
\hline Akraba yanı & 3 & 1.8 \\
\hline Toplam & 171 & 100.0 \\
\hline $\begin{array}{l}\text { Aylık Bireysel Giderlerini } \\
\text { Karşılama }\end{array}$ & f & $\%$ \\
\hline Harçlik & 130 & 76.0 \\
\hline Burs & 35 & 20.5 \\
\hline Kredi & 3 & 1.8 \\
\hline İşte Çalışma & 3 & 1.8 \\
\hline Toplam & 171 & 100.0 \\
\hline
\end{tabular}

Araştırmada ilk olarak uluslararası öğrencilerin profili belirlenmiştir. Öğrenci profiline ilişkin bulgular, Tablo 1., Tablo 2. ve Tablo 3.'te sunulmuştur. 
Araştırmada cinsiyet, hayatının büyük bölümünü geçirdiği yer, Edirne'de yaşadığı/yaşayacağı yer ve aylık bireysel giderlerini karşılama değişkenine ait frekans ve yüzdelik dağılımı Tablo 1'de gösterilmiştir. Araştırma grubunun \%72.5'ini kadın, \%27.5'ini ise erkek öğrenciler oluşturmaktadır. Hayatının büyük bölümünü geçirdiği yer değişkenine ait frekans ve yüzdelik dağılımı ise; \%39.8'i köykasaba, \%25.1'i büyükşehir, \%24.6's1 il ve \%10.5'i ilçede yaşamış uluslararası öğrenciler oluşturmaktadır. Edirne'de yaşadığı yer değişkenine ilişkin yüzdelik dağılım incelendiğinde; \%63.2'sinin yurtta, \%35.1'inin evde ve \%1.8'inin akraba yanında yaşadığı görülmektedir. Araştırmada uluslararası öğrencilerin aylık bireysel giderlerini karşılama değişkenine ait frekans ve yüzdelik dağglımı ise; \%76.0'sının harçlık, \%20.5'inin burs, \%1.8'inin kredi ve işte çalışarak bireysel giderlerini karş1ladığı görülmektedir.

Tablo 2. Fakülte, üniversiteye girdiği yıl ve bölümünü tercih sırası değişkenine ait frekans ve yüzdelik dağılım

\begin{tabular}{|c|c|c|}
\hline Fakültte & f & $\%$ \\
\hline Sağlık Bilimleri & 48 & 28.1 \\
\hline Eğitim & 29 & 17.0 \\
\hline İİBF & 15 & 8.8 \\
\hline Edebiyat & 15 & 8.8 \\
\hline Tip & 13 & 7.6 \\
\hline Eczac1lik & 12 & 7.0 \\
\hline Mühendislik & 11 & 6.4 \\
\hline MYO & 11 & 6.4 \\
\hline Mimarlik & 6 & 3.5 \\
\hline İlahiyat & 5 & 2.9 \\
\hline Diş & 3 & 1.8 \\
\hline Fen & 3 & 1.8 \\
\hline Toplam & 171 & 100.0 \\
\hline Üniversiteye Girdiği Yıl & f & $\%$ \\
\hline Liseyi bitirdiği yıl & 134 & 78.4 \\
\hline İkinci deneme & 23 & 13.5 \\
\hline Üçüncü deneme & 9 & 5.3 \\
\hline Dört ve üzeri deneme & 5 & 2.9 \\
\hline Toplam & 171 & 100.0 \\
\hline Bölümünü Tercih Sırası & f & $\%$ \\
\hline 1,00 & 96 & 56.1 \\
\hline 2,00 & 30 & 17.5 \\
\hline 3,00 & 25 & 14.6 \\
\hline 4,00 & 10 & 5.8 \\
\hline 5,00 & 4 & 2.3 \\
\hline 6,00 & 6 & 3.5 \\
\hline Toplam & 171 & 100.0 \\
\hline
\end{tabular}

Araştırmada fakülte, değişkenine ilişkin Tablo 2'deki yüzdelik dağılım incelendiğinde; \%28.1'ini sağlık bilimleri, \%17.0'ını eğitim, \%8.8'ini İ̈BF ve edebiyat, \%7.6'sını tıp, \%7.0'1nı eczacılık, \%6.4'ünü mühendislik ve MYO, \%3.5'ini mimarlık, \%2.9'ünü ilahiyat, \%1.8'ini diş ve fen fakültesinin oluştuğu anlaşılmaktadır. Araştırma kapsamındaki uluslararası öğrenciler üniversiteye girdiği y1l değişkenine göre incelendiğinde, \%78.4'nün liseyi bitirdiği y1l, \%13.5'inin ikinci, \%5.3'ünün üçüncü, \%2.9'unun dördüncü ve üzeri denemede üniversiteye yerleştikleri görülmektedir. Araştırmada uluslararası öğrencilerin bölümünü tercih sırası değişkenine ait frekans ve yüzdelik dağılımı incelendiğinde ise; \%56.1'i birinci sırada, \%17.5'i ikinci, \%14.6's1 üçüncü, \%5.8'i dördüncü, \%3.5'i altıncı ve \%2.3'ü beşinci sırada tercih ettiği görülmektedir. 
Tablo 3. Trakya Üniversitesi'ni ve okuyacağı bölümü tercih etme nedenleri değişkenine ait frekans ve yüzdelik dağılımları

\begin{tabular}{|c|c|c|}
\hline \multicolumn{3}{|c|}{ Trakya Üniversitesini Tercih } \\
\hline Kaliteli eğitim & 59 & 34.5 \\
\hline Puanının tutması & 53 & 31.0 \\
\hline Gelecekte iş imkânı & 28 & 16.4 \\
\hline Öğretmen/çevre önerisi & 26 & 15.2 \\
\hline İnternet araştırmaları & 15 & 8.8 \\
\hline Tanitımlardan etkilenme & 13 & 7.6 \\
\hline Aile baskisı & 4 & 2.3 \\
\hline \multicolumn{3}{|c|}{ Trakya $\quad$ Üniversitesinde } \\
\hline \multirow{2}{*}{\multicolumn{3}{|c|}{$\begin{array}{l}\text { Okuyacağı Bölümü Tercih } \\
\text { Etme Nedenleri }\end{array}$}} \\
\hline & & $\%$ \\
\hline Özel İlgi & 85 & 49.7 \\
\hline Gelecekte iş imkânı & 55 & 32.2 \\
\hline Aile/çevre önerisi & 20 & 11.7 \\
\hline Bölümdeki eğitimin kalitesi & 15 & 8.8 \\
\hline Öğretmen yönlendirmesi & 8 & 4.7 \\
\hline Tanitımlardan etkilenme & 5 & 2.9 \\
\hline
\end{tabular}

Araştırmada uluslararası öğrencilerin Trakya Üniversitesi'ni tercih etme nedenleri değişkenine ait frekans ve yüzdelik dağılımı Tablo 3'te gösterilmiştir. Araştırma grubunun \%34.5'i kaliteli eğitim, \%31.0'i puanın tutmas1, \%16.4'ü gelecekte iş imkân1, \%15.2'si öğretmen/çevre önerisi, \%8.8'i internet araştırmaları, \%7.6'sı tanıtımlardan etkilenme ve \%2.3'ü ise aile baskısını tercih nedeni olarak göstermiştir.

Araştırmada uluslararası öğrencilerin Trakya Üniversitesi'nde okuyacağı bölümü tercih etme nedenleri değişkenine ait frekans ve yüzdelik dağılımı incelendiğinde \%49.7'si özel ilgi, \%32.2'si gelecekte iş imkânı, \%11.7'si aile/çevre önerisi, \%8.8'i bölümdeki eğitimin kalitesi, \%4.7'si öğretmen yönlendirmesi, \%2.9'u tanıtımlardan etkilenmeyi neden olarak göstermiştir.

\subsection{Yeni Kayıt Yaptıran Öğrencilerin Oryantasyon Gereksinimlerine İlişkin Bulgular}

Araştırmada ayrıca öğrencilerin oryantasyon gereksinimleri belirlenmiştir. Buna yönelik bulgulara Tablo 4., Tablo 5., Tablo 6., Tablo 7., Tablo 8., Tablo 9. ve Tablo 10.'da yer verilmiştir.

Tablo 4. Trakya Üniversitesi hakkında bilgi edinme değişkenine ait frekans ve yüzdelik dağılımları

\begin{tabular}{lll}
\hline Trakya Üniversitesi Hakkında Bilgi Edinme & f & $\mathbf{\%}$ \\
\hline Kazandığım bölümün dersleri & 110 & 64.3 \\
Uluslararası ögrenci değişim programları & 108 & 63.2 \\
Kredi, burs, katkı payı vb. Olanakları & 107 & 62.6 \\
Staj olanakları & 107 & 62.6 \\
Yurt dışı staj programları & 101 & 59.1 \\
Ders geçme sistemiyle ilgili yönetmelikler & 96 & 56.1 \\
Yurt ve barınma olanakları & 85 & 49.7 \\
Öğrencilerin düzenledikleri etkinlikler & 81 & 47.4 \\
Kurs olanakları & 81 & 47.4 \\
Kulüpler & 77 & 45.0 \\
Ulusal öğrenci değişim programları & 69 & 40.4 \\
Kariyer planlaması ile ilgili hizmetler & 69 & 40.4 \\
Çift ana dal ve yan dal programlarının & 65 & 38.0 \\
tanıtılması &
\end{tabular}




\begin{tabular}{lll}
\hline Sportif olanaklar & 58 & 33.9 \\
Yarı zamanlı çalışma olanakları & 58 & 33.9 \\
Sanatsal olanakları & 55 & 32.2 \\
Yatay ve dikey geçiş yönetmeliği & 54 & 31.6 \\
$\begin{array}{l}\text { Bölümler arası geçiş olanakları } \\
\text { Üniversite içindeki ve dışındaki sportif }\end{array}$ & 52 & 30.4 \\
yarışmalar & 48 & 28.1 \\
$\begin{array}{l}\text { Disiplin konularıyla ilgili yönetmelikler } \\
\text { Üniversite içindeki ve dişındaki sanatsal }\end{array}$ & 47 & 27.5 \\
etkinlikler & 38 & 22.2 \\
\hline
\end{tabular}

Uluslararası öğrencilerin Trakya Üniversitesi hakkında bilgi edinme değişkenine ait frekans ve yüzdelik dağılımı Tablo 4'te gösterilmiştir. Örneklemin \%64.3'ü kazandığım bölümün dersleri, \%63.2'si uluslararası öğrenci değişim programları, \%62.6's1 kredi, burs, katkı payı vb. olanakları ve staj olanaklar, \%59.1'i yurt dışı staj programları, \%56.1'i ders geçme sistemiyle ilgili yönetmelikler, \%49.7'si yurt ve barınma olanakları hakkında bilgi edinmeyi önemli bulmuşlardır.

Tablo 5. Trakya Üniversitesi'nde öğrenim göreceği yerleşkenin yakın çevresindeki önemli yerler hakkında bilgi edinme değişkenine ait frekans ve yüzdelik dağılım

\begin{tabular}{lll}
\hline $\begin{array}{l}\text { Yerleşkenin Yakın Çevresindeki Yerler } \\
\text { Hakkında Bilgi Edinme }\end{array}$ & f & \% \\
\hline Hastane ve sağlık merk. adres ve tel. no & 111 & 64.9 \\
Kütüphanelerin adres ve tel. no & 100 & 58.5 \\
Kitapçıların adres ve tel. No & 87 & 50.9 \\
Fotokopicilerin adres ve tel. no & 83 & 48.5 \\
Restaurant ve kafelerin adres ve tel. no & 75 & 43.9 \\
Taksi duraklarının adres ve tel. no & 69 & 40.4 \\
Bilet satış ofislerinin adres ve tel. No & 64 & 37.4 \\
Özel yurtların adres ve tel. No & 55 & 32.2 \\
Emlakç1ların adres ve tel. No & 55 & 32.2 \\
Müzelerin adres ve tel. No & 48 & 28.1 \\
Sinemaların tel. No & 47 & 27.5 \\
Uçak bileti satış yeri adres ve tel. No & 44 & 25.7 \\
Muhtarlık adres ve tel. No & 21 & 12.3 \\
\hline
\end{tabular}

Uluslararası öğrencilerin Trakya Üniversitesi’nde öğrenim göreceği yerleşkenin yakın çevresindeki önemli yerler hakkında bilgi edinme değişkenine ait frekans ve yüzdelik dağılımı Tablo 5'te gösterilmiştir. Araştırma grubunun \%64.9'u hastane ve sağlık merkezlerin, \%58.5'i kütüphanelerin, \%50.9'u kitapçıların, \%48.5'i fotokopicilerin, \%43.9'u restaurant ve kafelerin, $\%$ 40.4'ü taksi duraklarının adres ve telefon numaraları hakkında bilgi edinmeyi önemli bulmuşlardır.

Tablo 6. Yerleşke hakkında bilgi edinme değişkenine ait frekans ve yüzdelik dağılım

\begin{tabular}{lll}
\hline Yerleşke Hakkında Bilgi Edinme & f & \% \\
\hline Kütüphane & 105 & 61.4 \\
Psikolojik danışma ve rehberlik hizmetleri & 84 & 49.1 \\
Dekanlık, öğrenci işleri, derslikler & 83 & 48.5 \\
Yaşam merkezi ve ders kitapları satış yerleri & 81 & 47.4 \\
Sosyal tesisler & 81 & 47.4 \\
Kültür merkezi & 75 & 43.9 \\
Koruma ve güvenlik hizmetleri & 63 & 36.8 \\
\hline
\end{tabular}




\begin{tabular}{lll}
\hline Büyük kafeterya/yemekhane ve restoranları & 59 & 34.5 \\
Haberleşme olanakları ve bankaları & 54 & 31.6 \\
\hline
\end{tabular}

Uluslararası öğrencilerin yerleşke hakkında bilgi edinme değişkenine ait frekans ve yüzdelik dağılımı Tablo 6'da gösterilmiştir. Araştırma grubunun \%61.4'ü kütüphane, \%49.1'i psikolojik danışma ve rehberlik hizmetleri, \%48.5'i Dekanlık, öğrenci işleri, derslikler, \%47.4'ü yaşam merkezi ve ders kitapları satış yerleri ve sosyal tesisler hakkında bilgi edinmeye ihtiyaç duymaktadırlar.

Tablo 7. Yerleşkede bulunan faaliyetler hakkında bilgi edinme değişkenine ait frekans ve yüzdelik dağılım

\begin{tabular}{llll}
\hline Yerleşkede Bulunan Faaliyetler Hakkında Bilgi & f & \% \\
Edinme & & \\
\hline Öğrenci toplulukları & 96 & 56.1 \\
Söyleşi, konferans, seminer, çalıştay gibi etkinlikler & 92 & 53.8 \\
Projeler & 87 & 50.9 \\
Spor olanakları & 85 & 49.7 \\
Yerleşke genelinde düzenlenen "Bahar Şenlikleri”, & 49 & 46.2 \\
sinema-tiyatro gösterileri gibi sosyal ve sanatsal & \\
etkinlikler & \\
\hline
\end{tabular}

Uluslararası öğrencilerin yerleşkede bulunan faaliyetler hakkında bilgi edinme değişkenine ait frekans ve yüzdelik dağılımı Tablo 7'de gösterilmiştir. Araştırma grubunun \%56.1'i öğrenci toplulukları, \%53.8'i söyleşi, konferans, seminer, çalıştay gibi etkinlikler, $\% 50.9$ 'u projeler, \%49.7'si spor olanakları gibi faaliyetler hakkında bilgi edinmeyi önemli bulmuşlardır.

Tablo 8. Öğrenim görülecek bölümle ilgili olması istenilen faaliyetler değişkenine ait frekans ve yüzdelik dağılım

\begin{tabular}{lll}
\hline $\begin{array}{l}\text { Öğrenim Görülecek Bölümle İlgili Olması İstenilen } \\
\text { Faaliyetler }\end{array}$ & f \\
\hline Diğer uluslararası öğrencilerle tanışmayı & 113 & 66.1 \\
$\begin{array}{l}\text { Bölümündeki öğretim elemanlarılla tanışma toplantısı } \\
\text { Diğer Türk öğrencilerle tanışmayı }\end{array}$ & 80 & 52.6 \\
$\begin{array}{l}\text { Bölümün ve Fakültenin/Yüksekokulun bulunduğu binayı } \\
\text { tanımayı }\end{array}$ & 63 & 36.0 \\
\hline $\begin{array}{l}\text { Bölümün ve Fakültenin/Yüksekokulun tarihsel } \\
\text { geçmişini öğrenmeyi }\end{array}$ & & 33.3 \\
\hline
\end{tabular}

Uluslararası öğrencilerin öğrenim görecekleri bölümle ilgili olmasını istedikleri faaliyetler değişkenine ait frekans ve yüzdelik dağılımı Tablo 8'de gösterilmiştir. Araştırma grubunun \%66.1'i diğer uluslararası öğrencilerle tanışmayı, \%52.6'sı bölümündeki öğretim elemanlarıyla tanışma toplantısını, \%52.0’1 diğer Türk öğrencilerle tanışmayı, \%36.8’i bölümün ve fakültenin/yüksekokulun bulunduğu binayı tanımaya yönelik faaliyetlerin olmasını istemişlerdir. 
Tablo 9. Psikolojik sağlı̆̆ın korunması ve geliştirilmesi hakkında bilgi edinme ya da beceri geliştirme değişkenine ait frekans ve yüzdelik dağılım

\begin{tabular}{|c|c|c|}
\hline $\begin{array}{l}\text { Psikolojik Sağlığın Korunması ve } \\
\text { Geliştirilmesi Hakkında Bilgi Edinme ya } \\
\text { da Beceri Geliştirme }\end{array}$ & $\mathbf{f}$ & $\%$ \\
\hline Sinav kaygısı & 119 & 69.6 \\
\hline Stresle başetme yolları & 111 & 64.9 \\
\hline Verimli ders çalışma becerisi & 98 & 57.3 \\
\hline Kariyer gelişimi ve iş başvurusu yapma & 96 & 56.1 \\
\hline Karar verme becerileri & 93 & 54.4 \\
\hline Girişkenlik becerileri & 80 & 46.8 \\
\hline Etkili zaman yönetimi & 73 & 42.7 \\
\hline Depresyonla başetme & 65 & 38.0 \\
\hline Kaygıyla başetme & 60 & 35.1 \\
\hline Öfke denetleme & 60 & 35.1 \\
\hline Kişilerarası iletişim ve çatışma çözme & 54 & 31.6 \\
\hline Mükemmeliyetçilik duygusuyla başetme & 37 & 21.6 \\
\hline Karşı cinsle yakın ilişkiler kurma becerileri & 35 & 20.5 \\
\hline Cinsellik ve korunma yöntemleri & 34 & 19.9 \\
\hline Alkol ve madde bağımlılığıyla başetme & 33 & 19.3 \\
\hline
\end{tabular}

Uluslararası öğrencilerin psikolojik sağlığın korunması ve geliştirilmesi hakkında bilgi edinme ya da beceri geliştirme değişkenine ait frekans ve yüzdelik dağılımı Tablo 9'da gösterilmiştir. Araştırma grubunun \%69.6'sı sınav kaygısı, \%64.9'u stresle başetme yolları, \%57.3'ü verimli ders çalışma becerisi, \%56.1'i kariyer gelişimi ve iş başvurusu yapma, \%54.4'ü karar verme becerileri, \%46.8'i girişkenlik becerileri hakkında bilgi edinme ve beceri geliştirmeyi önemli bulmuşlardır.

Tablo 10. Yararlanılmak istenilen psikolojik danışma ve rehberlik hizmetleri değişkenine ait frekans ve yüzdelik dağılım

\begin{tabular}{|c|c|c|}
\hline $\begin{array}{l}\text { Yararlanılmak İstenilen Psikolojik Danışma ve } \\
\text { Rehberlik Hizmetleri }\end{array}$ & $\mathbf{f}$ & $\%$ \\
\hline Bireyle psikolojik danışma & 100 & 58.5 \\
\hline $\begin{array}{l}\text { Kariyer planlama becerileri kazandırmaya yönelik } \\
\text { etkinlikler/çalışmalar }\end{array}$ & 84 & 49.1 \\
\hline Seminerler/ Toplantılar & 73 & 42.7 \\
\hline $\begin{array}{l}\text { Öğrencilerin yaşadıkları kriz durumlarına yönelik } \\
\text { hizmetler }\end{array}$ & 54 & 31.6 \\
\hline Akran rehberliği & 48 & 28.1 \\
\hline $\begin{array}{l}\text { Üniversitemizdeki Psikolojik Danışma ve Rehberlik } \\
\text { Birimi’nin web sayfasında çeşitli konuları kapsayan } \\
\text { broşürler }\end{array}$ & 48 & 28.1 \\
\hline Çalışma grupları & 44 & 25.7 \\
\hline Grupla psikolojik danışma & 38 & 22.2 \\
\hline
\end{tabular}

Uluslararası öğrencilerin yararlanılmak istenilen psikolojik danışma ve rehberlik hizmetleri değişkenine ait frekans ve yüzdelik dağılımı Tablo 10'da gösterilmiştir. Araştırma grubunun \%58.5'i bireyle psikolojik danışma, \%49.1'i kariyer planlama becerileri kazandırmaya yönelik etkinlikler/çalışmalar, \%42.7'si seminerler/ toplantılar, \%31.6'sı öğrencilerin yaşadıkları kriz durumlarına yönelik hizmetlerden yaralanmak istemeyi önemli bulmuşlardır. 


\section{TARTIŞMA ve SONUÇ}

Araştırmanın birinci amacı olan uluslararası öğrenci profilini belirleme çalışmasından elde edilen sonuçlar şöyledir: Trakya Üniversitesi'nde eğitim-öğretim gören uluslararası öğrencilerin büyük çoğunluğu liseyi bitirdiği yıl üniversiteye başlayan, bulunduğu ülkede köy/kasabada yaşayan, yurtta kalan, ailesinden harçlik alarak geçinen öğrencilerden oluşmaktadır. Öğrenciler, ağırlıklı olarak sağlık bilimleri ve eğitim fakültesini tercih etmişler; çoğu ilk tercihine yerleşmiştir. Öğrencilerin Trakya üniversitesini tercih etme nedenleri arasında en fazla kaliteli eğitim ve puanın tutması; en az internet araştırmaları ve tanıtımlardan etkilenme yer almaktadır. Bölüm tercihini etkileyen nedenler arasında ise en fazla özel ilgi duyma, iş imkânı ve aile yer alırken; en az tanıtımlardan etkilendikleri görülmüştür. Uluslararası yükseköğretim hareketliliği ve Türkiye'nin konumu raporuna göre (Dış Ekonomik İlişkiler Kurulu, 2013), öğrenciler çalışmak istediği alanda en iyi eğitimi veren ülke ve okulu tercih etmektedirler. Başka bir deyişle; eğitimin kalitesi, eğitim süreciyle bağlantılıdır. Bu tam anlamıyla eğitimde ülkenin akademik saygınlığa sosyal desteğe ve farklılıklara anlayışa işaret etmektedir. Ayrıca akademik kaynakların yeterliliği ve akademisyenlerin öğretme kabiliyeti de ülkenin eğitim kalitesini belirleyen hususlar arasındadır (DEİK, 2017). Benzer şekilde, Karabük Üniversitesinde uluslararası öğrencilerle yapılan durum analizi çalışmasının sonucunda, öğrencilerin ülke, üniversite ve bölüm tercihleri arasında, gelişmiş ülke imajı, puanın yeterli olması, eğitim kalitesi ve bölüme ilgileri olduğu bulunmuştur (Yıldıran ve ark., 2016). Tekelioğlu ve ark. (2012), uluslararası öğrencilerin ülke ve üniversite seçimini etkileyen faktörlerle ilgili yapmış oldukları araştırmanın sonucunda, Türkiye'deki üniversitelerin ve eğitim kalitesinin kendi ülkeleri ile kıyasladıklarında daha iyi ve ileri olması, eğitim ücreti ve burs imkânı gibi faktörlerin etkili olduğu görülmüştür. Aynı araştırmanın bir diğer sonucu, uluslararası tanınırlığın yetersiz olması, firsatların ve imkânların uluslararası platformlarda yeterince ifade edilemediği gerçeğidir. Bu durum, üniversitelerin yurtdışında tanınırlığını arttırma konusundaki çabalarını yeniden gözden geçirmeleri gerektiğine işaret etmektedir.

Araştırmanın ikinci amacı olan uluslararası öğrencilerin oryantasyon gereksinimlerini belirleme çalışmasından elde edilen sonuçlar; öğrencilerin yerleşke dışında kalan yakın çevre, yerleşke ve yerleşkedeki sosyal faaliyetler hakkında bilgi edinme ihtiyacında olduklarıdır. Öğrencilerin, üniversite ile ilgili bilgi edinmek istedikleri konular sırasıyla; kazandığı bölümü tanımak, öğrenci değişim programları, kredi/burs, staj, yurt/barınma, devamında da akademik hizmetler ve sosyal etkinlikler hakkında bilgi almak olmuştur. Yükseköğrenime yeni başlayan öğrencilerin gittikleri ülke/şehri tanımaması, üniversiteyle, yönetim, program ve öğretimle ilgili uyulması gereken kuralları bilmemesi ve aileden ilk kez ayrılmaları öğrencilerin ilk zamanlarda bocalamasına neden olmaktadır (Kolunsağ ve Vatansever-Özdemir, 2007). Öğrenmeleri ve çevreyi tanımaları uzunca bir zaman aldı̆̆ 1 için deneme yanılma yoluyla bir şeyleri öğrenmeye çalışmaları zaman kaybı ve uyum sorunlarına neden olmaktadır. Bu aşamada dikkat edilmesi gereken husus, bu durumda olan öğrencilere ihtiyaçlarına yönelik destek faaliyetlerinin ve bilgilendirmelerin yapılmasıdır (Korkmaz, 2000). Öğrencilerin bölümlerinde olmasını istedikleri oryantasyon etkinlikleri, tanışma etkinlikleridir. Öğrenciler en çok kendi gibi olan uluslararası öğrencilerle tanışmak istemektedirler. Yabancı bir ülkeye yeni gelmiş olan kimselerin çoğu, uyum süreçlerinin başında ev sahibi ülke üyeleriyle sınırlı düzeyde etkileşimde bulunurlar ve bu kimselerle bireylerarası iletişimi genellikle stresli bulurlar (Özçetin, 2013). Bu sebepten dolayı kendi dili, inancı ve kültürüne yakın arkadaşlık arayışında olmaları, üst sınıflardaki uluslararası öğrencilerin rehberliği uyum sağlama sürecinde beklendik bir durum denebilir.

Psikolojik danışma ve rehberlik hizmetleri bağlamında, uluslararası öğrencilerin sıklıkla yardım alma ihtiyacı içinde oldukları konular; sınav kaygısı, stresle başa çıkma, verimli ders çalışma, kariyer gelişimi ve iş başvurusu yapma, karar verme becerisi geliştirme ve girişkenlik olup; öğrenciler en çok bireysel psikolojik danışma hizmetinden yararlanma ihtiyacı 
içindedirler. Bireyin, çevrenin taleplerine birey veya grup olarak kendisini uyarlayabilme yeteneğine psikolojik uyum denilmektedir (Kılıçlar, Sarı ve Seçilmiş, 2012). Zhang ve Goodson (2011), hem lisans hem de lisansüstü uluslararası öğrencilerin psikososyal uyumunun yordayıcılarına odaklanan, Ocak 1990 ve Ocak 2009 arasında hakemli dergilerde yayınlanan altmış dört çalışmanın bir meta-analizini gerçekleştirmiştir. Bu çalışmanın sonunda, stres, sosyal destek, İngilizce yeterlilik, menşei ülke / ülke, Amerika Birleşik Devletleri'nde ikamet süresi, kültürleşme, Amerikalılarla sosyal etkileşim, öz-etkililik, cinsiyet ve kişilik gibi psikososyal uyumun anlamlı bir şekilde yordadığını bulmuşlardır. Eğitim sistemindeki farklı değerlendirme yöntemleri ve değerlendirme süresi özellikle onlar için stresli olabilir. Bazı öğrenciler, yazma konusunda iyidir, diğerleri ise çoktan seçmeli sınavlarda daha iyidir. Üniversitenin değerlendirme yöntemlerine aşina olmayan öğrenciler kayda değer kayg1 duyabilirler. Uluslararası öğrenciler, eğitmenlerinden test hazırlığ1 ve test çözme stratejileri hakkında rehberlik almaları konusunda teşvik edilmelidir. Üniversite, öğrencilerin kayıt, müfredat ve derecelendirme sistemleri hakkında bilgi ve bilgi sahibi oldukları bir ortam yaratarak öğrencilerin kaygılarını hafifletebilir. Oryantasyon, uluslararası öğrenciler için ağ oluşturma ve özel ders, kütüphane ve danışmanlık hizmetleri gibi kaynakları belirlemek için altın bir firsattır (Mesidor ve Sly, 2016). Öğrencilerin yardım aramaya ilişkin tutumları incelendiğinde; Özçetin (2013)'in araştırmasına katılan uluslararası öğrencilerin \%63.3'ü $(n=140)$ yaşadığ 1 problemleri kendisinin çözmeye çalıştığını ifade ederken \%35.3'ü $(n=78)$ mutlaka ilgili yerlerden yardım isteyeceğini belirtmiştir. Üniversite eğitimi için aynı ülke içinde yer değiştiren gençler bile uyum sorunu yaşarken, farklı ülkeden gelen gençler için bu durum kaçınılmazdır. Bazı uluslararası öğrenciler ev sahibi ülkeye uyum sağlamaya çalışırken depresyon, anksiyete, akademik zorluklar, ilişki sorunları (Nilsson ve ark., 2004; Yi ve ark., 2003; Yokuşko ve ark., 2008), yalnızlık ve kültürel uyum ile uğraşırlar (Yokushko ve ark., 2008). Öğrencilerin uyumunu desteklemek için psikolojik danışma hizmetlerinin daha etkili ve uluslararası öğrenci sorunlarına duyarlı olması gerekmektedir.

$\mathrm{Bu}$ çalışma, Trakya Üniversitesi merkez kampüsünde eğitim-öğretim gören uluslararası öğrencilerle sınırlıdır. Araştırmanın sonuçları, uluslararası öğrencilerin ihtiyaçlarına, üniversitenin amaç ve koşullarına göre öğrenci gelişimine ve uyumuna hizmet edebilecek planlı ve programlı iyi bir oryantasyon modeline ihtiyaç olduğunu göstermektedir. Oryantasyon ve akademik danışmanlık hizmetlerinin doğrudan alıcısı ve yararlanıcısı olarak öğrenciler, bu hizmetlerin verimliliği ve etkililiğini değerlendirme bakımından önemli bir veri kaynağıdırlar (Ekinci ve Burgaz, 2007). Öğrenci profili çalışmaları üniversitenin kendisini tercih eden öğrencilerin özelliklerini tanıması ve kendi kitlesine hitap edecek iyileştirmeler ve düzenlemeler yapması açısından önemli olacaktır. Gelişigüzel oryantasyon etkinlikleri düzenlemek yerine üniversitelerin öğrencilerin oryantasyon gereksinimlerine cevap verecek bir oryantasyon programının hazırlanması amaca daha uygun olacaktır.

Uluslararası öğrencilerin bir uyum/uyumsuzluk süreci yaşadıkları tartışılmaz bir gerçekliktir. Bundan dolayı bu öğrencilerin içinde bulundukları yaşam alanlarında (okul, yurt vb.) destek alabilecekleri bir danışmanlık birimi kurulması, uzman personelce diğer imkanları itibarıyla bu birimlerin desteklenmesi, karşılaşabilecekleri psikolojik risk ve sorunların giderilmesinde etkili olacaktır (Otrar ve ark, 2002). 


\section{KAYNAKLAR}

Acar Güvendir, M. (2018). The Relation of an International Student Center's Orientation Training Sessions with International Students' Achievement and Integration to University. Journal of International Students, 8 (2), 843-860.

Akbalık, G. (1999). Bilgilendirme ve grupla psikolojik danışmanın üniversite birinci sınıf öğrencilerinin üniversiteye uyumları üzerine etkisi. Ankara Üniversitesi Ĕ̈itim Bilimleri Fakültesi Dergisi, 30, 159180.

Coşkunserçe, O., \& Bedir-Erişti, S.D. (2016). Uluslararası öğrencilerin kültürel uyum sürecine yönelik tasarım tabanlı araştırma yaklaşımına dayalı çevrimiçi oryantasyon uygulamasının geliştirilmesi. Eğitim Teknolojisi Kuram ve Uygulama, 7(1), 83-104.

Cura, Ü., \& Işık, A. N. (2016). Uluslararası öğrencilerin akademik uyumuna kültürleşme stresi ve sosyal desteğin etkisi. Ĕgitim ve Bilim,41(184).

DEİK (Dış Ekonomik İlişkiler Kurulu) (2013). Uluslararası yükseköğretim ve Türkiye’nin konumu. Eğitim Ekonomisi İş Konsey Raporu, İstanbul.

Ekinci, C. E., \& Burgaz, B. (2007). Hacettepe Üniversitesi öğrencilerinin bazı akademik beklenti ve memnuniyet düzeyleri. Hacettepe Üniversitesi Eğitim Fakültesi Dergisi, 33, 120-134.

Kılıçlar, A., Sarı, Y., \& Seçilmiş, C. (2012). Türk dünyasından gelen öğrencilerin yaşadıkları sorunların akademik başarılarına etkisi: Turizm öğrencileri örneği. Bilig-Türk Dünyası Sosyal Bilimler Dergisi, 61, 157-172.

Kıroğlu, K., Kesten, A., \& Elma, C. (2010). Türkiye'de öğrenim gören uluslararası lisans öğrencilerinin sosyokültürel ve ekonomik sorunlar1. Mersin Üniversitesi Eğitim Fakültesi Dergisi, 6(2), 26-39.

Kolunsağ, A., \& Vatansever Özdemir, G. (2007). Sürdürülebilir oryantasyon modeli ve Sakarya Üniversitesi’ndeki durum. Sakarya Üniversitesi Eğitim Fakültesi Dergisi, 14, 211-229.

Kutlu, M. (2004). Üniversite öğrencilerinin alıştırma-oryantasyon hizmetlerine ilişkin karşılaştıkları sorunlar ve beklentileri. XIII. Ulusal Eğitim Bilimleri Kurultayı'nda sunulmuş bildiri. 6-9 Temmuz 2004 İnönü Üniversitesi, Eğitim Fakültesi, Malatya.

Mesidor, J.K., \& Sly, K.F. (2016). Factors that contribute to the adjustment of international students. Journal of International Students, 6(1), 262-282.

Nilsson, J. E., Berkel, L. A., Flores, L. Y., \& Lucas, M. S. (2004). Utilization rate and presenting concerns of international students at a university counseling center: Implications for outreach programming. Journal of College Student Psychotherapy, 19, 49-59.

Otrar, M., Ekşi, H., Dilmaç, B., \& Şirin, A. (2002). Türkiye'de öğrenim gören Türk ve akraba topluluk öğrencilerinin stres kaynakları, başaçıkma tarzları ile ruh sağlı̆̆ı arasındaki ilişki üzerine bir araştırma. Educational Science:Theory \& Practice, 2(2), 481-506.

Özçetin, E. (2013). Yükseköğrenim gören uluslararası öğrencilerin sosyal uyumlarını etkileyen etmenler. Yayımlanmamış Yüksek Lisans Tezi. Hacettepe Üniversitesi Sosyal Bilimler Enstitüsü, Ankara.

Özyürek, R., Arıkan, D., \& Şahin, M. (2016). Ege Üniversitesi öğrencilerinin oryantasyon ve akademik danışmanlık hizmetleri ile ilgili gereksinimlerinin belirlenmesi. International Journal of Human Sciences, 13(1), 1233-1270.

T.C. Resmî Gazete (1984). Yükseköğretim Kurumları Mediko-Sosyal Sağlı, Kültür ve Spor İşleri Dairesi Uygulama Yönetmeliği, 18301, s. 24-29, 3 Şubat 1984.

Sağırlı, M. (2007). Eğitimin küreselleşmesi. Sosyal Siyaset Konferanslarl Dergisi, 2007, 53 (1). www.arastirmax.com/system/files/dergiler/51602/makaleler/53/1/arastirmax_9794__pp_423-475.pdf adresinden 11.06.2018 tarihinde elde edilmiştir.

Tekelioğlu, S., Başer, H., Örtlek, M., \& Aydınlı, C. (2012). Uluslararası öğrencilerin ülke ve üniversite seçiminde etkili faktörler: Vakıf Üniversitesi örneği. Organizasyon ve Yönetim Bilimleri Dergisi, 4(2), 191-200.

Yakushko, O., Davidson, M., \& Sanford-Martens, T. C. (2008). Seeking help in a foreign land: International students' use patterns for a U.S. university counseling center. Journal of College Counseling, 11(1), 618.

Yıldıran, C., Özkan, D., \& Büyükyılmaz, O. (2016). Uluslararası lisans öğrencilerinin durum analizi: Karabük Üniversitesi. Uluslararası Bilimsel Araştırmalar Dergisi, 1(1), 20-34. doi number :http://dx.doi.org/10.21733/IBAD.35

Yi, J. K., Lin, J. C. G., \& Kishimoto, Y. (2003). Utilization of counseling services by international students. Journal of Instructional Psychology, 30(4), 333-342.

Zhang, J., \& Goodson, P. (2011). Predictors of international students'psychosocial adjustment to life in the United States: A systematic review. International Journal of Intercultural Relations 35(2), 139-162. 